\title{
Smart Classroom: Need of the hour for Madhya Pradesh Government Schools
}

Piyush Prakash Yadav

MA (Pursuing at Charles University), LLB, B.COM)

Electronic version

URL: http://www.researchambition.com

DOI: https://doi.org/10.53724/ambition/v5n4.02

ISSN: 2456-0146

Vol. 5, Issue-IV, February 2021

Page No. 01-05

Publisher

Welfare Universe

email: publish2017@gmail.com

CResearch Ambition: An International Multidisciplinary e-Journal 2021. This Open Access article is published under a Creative Commons Attribution Non-Commercial 4.0 International License https://creativecommons.org/licenses/by-nc/4.0/, which permits non-commercial reuse, distribution, and reproduction in any medium, provided the original work is properly cited. For citation use the DOI. For commercial re-use, please contact editor email:- publish2017@ gmail.com By accessing the work you hereby accept the Terms. Non-commercial uses of the work are permitted without any further permission from Research Ambition: An International Multidisciplinary eJournal provided the work is properly attributed. 


\title{
Smart Classroom: Need of the hour for Madhya Pradesh Government Schools
}

${ }^{*}$ Piyush Prakash Yadav

\begin{abstract}
:
Smart classrooms are the technology equipped classrooms which promotes the learning by using technology devices such as computer, Internet, Projector, Videos/audios capabilities device, artificial Intelligence etc. Smart classroom has come out of the technological revolution and digital initiative which has transformed the education sector. Smart classroom has addressed the various problems like quality of education, improvement in student's performance, creative learning etc. The smart classroom concept has also changed the traditional rote learning methods. The smart classroom market rising very rapidly in India rapidly India has lacs of smart classrooms setup installed in Private and government institution. Madhya Pradesh government has put forward agenda lot of time but couldn't acted responsibly. The current paper throws the light on the effectiveness of smart classrooms, the problems in education sector and shows that the smart classroom is in an urgent need for improving the quality of education in Madhya Pradesh.
\end{abstract}

Key Words: Smart Classroom, Information and Communication Technology, Learning, Quality of education.

\section{Introduction}

Technology has changed every sector of the life, likewise during last decades technology has transformed education sector whether in a way of delivering knowledge or technological devices used in delivering the education. India has taken many steps towards technological revolution in education sector like E-learning, Massive open online learning, smart classrooms etc. The initiative of technological use in an education sector was also seen in New National Education Policy 2020. ${ }^{1}$ Covid19 has also shown the importance of Technology in education and lack of facilities in the countries

\footnotetext{
* MA (Pursuing at Charles University), LLB, B.COM)

1 Ministry of Human Resource Development, 2020: National Educational Policy 2020: [online] Available at: <https://www.education.gov.in/sites/upload_files/mhrd/files/NEP_Final_English_0.pdf> [Accessed 3 February 2021].
} 
education system. Smart classroom in some state of India has achieved greater milestone, while the central government has taken some big steps to transform the education system ${ }^{2}$

Madhya Pradesh is the $5^{\text {th }}$ populated state and $2^{\text {nd }}$ largest state by area in India. The literacy rate of Madhya Pradesh is approx. 70\% according to census $2011 .^{3}$ As per ASER 2018, the difference between the government and private school performance of children $\%$ of class VIII who can division is $32.1 \%$ and $52 \%$ in Madhya Pradesh. Also \% children of class VIII who can read the class II text is $57.9 \%$ in government schools and $86.3 \%$ private schools. ${ }^{4}$ There is a significant gap in the private and government school. Quality of education was always a major concern in government school education. Although in few government and private schools they have adopted smart classrooms.

\section{Cognitive Problem}

The growing population of India has affected all the sectors and Education sector is one of them. It is very hard to provide good quality of education to huge amount of people. Madhya Pradesh has many problems in education sector which was resulted in bad quality of education. As indicated by Annual status of Education report 2018 in Madhya Pradesh rustic 2.4\% Children of VIII class can't read a letter, $10.5 \%$ Children of VIII class just read a letter, $8.3 \%$ Children of VIII class can read a word, children of VIII class who can read the I class text is only $14.5 \%$ and $30.8 \%$ children can't perceive the number 10-99, 20.8\% kids can't do deduction and 36.6 can't do essential division. ${ }^{5}$ Primarily infrastructure was always shown as the hurdles in education sector but there are some other issues as well because of which the quality of education provided in government school is low. The shortage of motivated and well trained is one of the important reasons for the low quality of Education. ${ }^{6}$ Technology may help to improve the quality of education in the schools.

\section{Review of Literature:}

By setting up smart classroom on campus in government schools will help to increase accessibility to quality education in government schools. Many studies have found that smart classroom is more effective than the traditional classrooms. It is statistically proved that the student studying in

\footnotetext{
${ }^{2}$ The New Indian Express. 2019. Rs 9,000 crore for 'smart classrooms' in Delhi government schools. [online] Available at: <https://www.newindianexpress.com/cities/delhi/2019/dec/25/rs-9000-crore-for-smart-classrooms-in-delhi-governmentschools-2080530.html> [Accessed 28 January 2021].

${ }^{3}$ Census2011.co.in. 2021. Madhya Pradesh Population Sex Ratio in Madhya Pradesh Literacy rate data 2011-2021. [online] Available at: <https://www.census2011.co.in/census/state/madhya+pradesh.html> [Accessed 21 February 2021].

${ }^{4}$ ASER Centre, 2018. Annual Status Education Report 2018: [online] Available at: <http://img.asercentre.org/docs/ASER\%202018/Release\%20Material/English\%20files/madhyapradesh.pdf> [Accessed 11 May 2020].

${ }^{5}$ ASER Centre, 2018. Annual Status Education Report 2018: [online] Available at: <http://img.asercentre.org/docs/ASER\%202018/Release\%20Material/English\%20files/madhyapradesh.pdf> [Accessed 11 May 2020].

${ }^{6}$ Pratibha Parv: Strengthening quality of education in government schools of Madhya Pradesh, 2015. Social Sector Service Delivery: Good Practices Resource Book 2015. pp.39-43.
} 
smart classrooms scores more than the one in conventional classrooms. The study was conducted for the student of class VIII in mathematics subject. ${ }^{7}$ The study was also conducted in chemistry subject in schools and it was found that the student of smart classroom has achieved higher achievement than the students who were taught in traditional way. ${ }^{8}{ }^{9}$ The smart classroom learning environment was also found to be better to teach rural low achiever and high achiever in science. ${ }^{10}$

A technology play an important role in our daily lives and it is now has become a way of life. Technology has helped humankind in every aspect of life from communication to education. Technology has progressed to improve the quality of instruction as it is changed and improved over the year. Because of technology we can change our education system of rote learning and provide students with innovative learning solutions with the use of the projector and computer. With the help of smart classrooms the students will learn in different ways even if it is non-interactive like displaying the photos, illustrations, maps, graphs and videos. ${ }^{11}$

Using technology in the education was adopted my many countries in 1990s. Like Malaysia's smart school initiative is started in 1996 aiming to make a smart classrooms and making learning creative with the help of information and communication technologies (ICT) framework. It is statistically proved that student's performance is improved and the success, interest, training and curriculum assessment variables are high. ${ }^{12}$ Smart classroom apart from improving performance of student it can also pull up the interest, helps in training and improve curriculum assessment skills of the students.

\section{Discussion and Implications}

Smart classroom usually comes in two type one is interactive and the other is non-interactive.

The interactive version of smart classroom which has more equipped with technological device through which the student can touch the screen and the system can respond by analyzing the gesture of student

\footnotetext{
${ }^{7}$ Anju and Sharma, H., 2016. Effectiveness of EDUCOMP smart classroom teaching on achievement in mathematics at elementary level. [online] Available at:

<https://www.researchgate.net/publication/323336049_Effectiveness_of_EDUCOMP_smart_classroom_teaching_on_achie vement_in_mathematics_at_elementary_level> [Accessed 21 February 2021].

${ }^{8}$ Kaur, R., 2018. TO STUDY THE EFFECTIVENESS OF CONCEPT ATTAINMENT MODEL OF TEACHING ON ACHIEVEMENT OF SECONDARY SCHOOL STUDENTS IN CHEMISTRY. Scholarly Research Journal for Humanity Science \& English Language, 5(25).

${ }^{9}$ Menon, A., 2015. EFFECTIVENESS OF SMART CLASSROOM TEACHING ON THE ACHIEVEMENT IN CHEMISTRY OF SECONDARY SCHOOL STUDENTS. [online] Iasir.net. Available at: <http://iasir.net/AIJRHASSpapers/AIJRHASS15132.pdf> [Accessed 21 February 2021].

${ }^{10}$ Jena, P., 2013. Effect of Smart Classroom Learning Environment on Academic Achievement of Rural High Achievers and Low Achievers in Science. [online] Ceeol.com. Available at: 〈https://www.ceeol.com/search/article-detail?id=161324> [Accessed 21 February 2021].

${ }^{11}$ Takawale, N. and Kulkarni, S., 2016. Effectiveness of Smart Classroom over Traditional Classroom in Terms of Academic Achievement of Students Using Statistical Method. International Journal of Innovative Research in Computer and Communication Engineering, 4(02).

${ }^{12}$ Omidinia, S \& Masrom, M \& Selamat, H. (2012). Determinants of smart school system success (case study of Malaysia).
} 4. 
through AI technology, there is no need of even black and white board to conduct the class. Interactive smart classroom will be expensive to setup in all the schools. The second type of smart classrooms is non-interactive one in which there will be less device needed to teach the class. The white board might be needed for giving classes but the countries one of the best classes will be given to any children in any part of country. ${ }^{13}$ If I have to give suggestion to state government then I would suggest providing a laptop and projector in school classes. The suggestion is might be similar to non-interactive smart classrooms but it is even less expensive than the non-interactive smart classrooms. The logic behind this kind of setup is that the countries best teacher's course will be presented to any school as there are many ways of learning the same thing. The laptop and projector will make the class more interesting by showing videos, audios, pictures, graph etc as this will pull up the interest of the students.

\section{Results}

From the above research we have found that the smart classroom are more effective in improving the students' performance as well as it will pull up the interest, skills etc. of student. In many states of India, there are many smart classrooms which are going on and many states have given priority to setup the smart classroom. ${ }^{14}$

Pandemic has shown to so many countries the mirrors of their weaknesses and the strengths of the various areas. In India's case there is major gap in the internet access in urban and rural areas. In urban areas there is a 93\% person who has a broadband penetration on the other way in rural areas it is just 29.2\%. Whilst in Madhya Pradesh comes in the category of one of the least number of internet subscribers per 100 persons in rural areas which is $23.88 \%$. ${ }^{15}$ There must be lot of improvement in the overall infrastructure facilities in rural areas like internet, proper toilets etc. Some of the steps which Madhya Pradesh government has taken in regard to internet facilities provided to rural areas and are planning setup Wifi services in the 13000 villages. ${ }^{16}$

\section{Conclusions}

The use of information communication technology in education will not only provide an education in different ways by displaying the photos, illustrations, maps, graphs and videos but also to

\footnotetext{
${ }^{13}$ The Statesman. 2018. Digital Learning In India | How Smart Classrooms Are Changing The Face Of Education. [online] Available at: <https://www.thestatesman.com/education/digital-learning-india-smart-classrooms-changing-face-education1502669247.html> [Accessed 29 December 2020].

${ }^{14}$ The Statesman. 2018. Digital Learning In India | How Smart Classrooms Are Changing The Face Of Education. [online] Available at: <https://www.thestatesman.com/education/digital-learning-india-smart-classrooms-changing-face-education1502669247.html> [Accessed 29 December 2020

${ }^{15}$ Sharma, S., 2020. Modi's 'Digital India' still a far-fetched dream for hinterland; not even $30 \%$ of rural India has internet. [online] The Financial Express. Available at: <https://www.financialexpress.com/economy/modis-digital-india-still-a-farfetched-dream-for-hinterland-not-even-30-of-rural-india-has-internet/2085452/> [Accessed 21 February 2021].

${ }^{16}$ News, C. and News, B., 2017. Wi-Fi connectivity: 13K MP villages to have Wi-Fi by 2017| Bhopal News - Times of India. [online] The Times of India. Available at: <https://timesofindia.indiatimes.com/city/bhopal/13k-mp-villages-to-have-wi-fiby-2017/articleshow/56427455.cms> [Accessed 31 January 2021].
} 
prepare the current generation students for a workplace where Information Communication and Technologies devices like computer and internet are becoming the most important tool for work in industries. The smart classrooms will not only improve the performance of the students but also the teachers. ${ }^{17}$ The current study is the attempt to show the effectiveness of smart classroom and how it is useful in improving the performance of student in schools through the previous research. This study also tries to explain the problems in the education system of Madhya Pradesh and how smart classroom can solve these problems. The study also suggested that there is urgent need of smart classrooms in Madhya Pradesh schools in order to improve the quality of education.

$* * * * * * * * * * * * * * * * * * * * * * * * * * * * *$

${ }^{17}$ Jan, H. and Noor ul alam, S., 2018. Smart Classroom a New Paradigm for Teaching and Learning: Its Implementation and Setback with Special Reference to J\&amp; K. [online] Academia.edu. Available at:

<https://www.academia.edu/36493357/Smart_Classroom_a_New_Paradigm_for_Teaching_and_Learning_Its_Implementat ion_and_Setback_with_Special_Reference_to_J_and_K> [Accessed 21 February 2021]. 